\title{
On the relationship between total quality management practices and firm performance in Vietnam: The mediating role of non-financial performance
}

\author{
Thi My Dung Phama*
}

${ }^{a} P h D$ candidate, Nagoya University, Japan

\begin{tabular}{l}
\hline C H R O N I C L E \\
\hline Article history: \\
Received: November 27, 2019 \\
Received in revised format: \\
November 292019 \\
Accepted: January 7, 2020 \\
Available online: \\
January 8, 2020 \\
\hline Keywords: \\
TQM practices \\
Financial performance \\
Non-financial performance \\
Mediator \\
Vietnamese enterprises
\end{tabular}

\section{Introduction}

Total Quality Management (TQM) is a management method that originated from the US in the 1950s, and it has steadily become more popular since the early 1980s in the global markets. TQM is considered as a holistic approach for long-term success with continuous improvement in all aspects of an organization as a continuous process, not as a short-term goal. Therefore, it refers to the way of not only managing for the future but also managing people and business processes to ensure customer satisfaction at every stage, both internally and externally. It cannot deny that TQM brings many benefits for firms, generally in promoting of growth, improving quality, employee participation, teamwork, working relationships, customer satisfaction, employee's satisfaction, productivity, communication and market share (Ahmad et al., 2013; Idris et al., 1996; Antony et al., 2002). In many large multinational corporations (MNCs) such as IBM, British Airways, Hewlett-Packard, Motorola, TQM is applied more common thanks to adapting with the high requirement of international competition. Also, it may enhance to achieve higher levels of quality achievement to meet the customer satisfaction. Meanwhile, for many small enterprises, obtaining quality certificates, for example, ISO standards, seem to be the quality destination for quality 
management (Yusof \& Aspinwall, 2000). For Vietnamese enterprises, quality has been seen as a crucial component for firm development, especially in the pace of globalization and economic integration. Vietnamese enterprises are required to adopt quality management methods flexibly to meet customer satisfaction. ISO standard, GMP, HACCP, SA8000 are international quality management systems which have been applied widely in Vietnam. Of which, ISO standard has been more familiar with Vietnamese enterprises, the number of companies achieved ISO certificates has increased rapidly. This certificate is recognized as a pre-condition for companies to advertise products and brands to the market for reaching customer's beliefs. However, these quality management systems are adopted under external pressure in proving the quality of products or services in the marketplace. In the long - term development, enterprises should be more active in quality management to enrich competitive advantages. Whereas, TQM is remarked as an approach that helps to connect effects for quality improvement gradually and build up the organizational culture where all employees commit to work for customer satisfaction and longterm business objectives. Therefore, moving toward TQM in Vietnamese enterprises is one of the continuous improvement trends for firm after achieving some quality standards in the first step of quality management systems to ensure sustainable development. Although the number of companies applying TQM has been increasing gradually since quality management systems introduced in 1995, it is not easy to implement TQM in Vietnamese enterprises due to lacking human resources, having no instructions, operational support, or tools. Based on this situation, the study intends to identify the status of TQM application with the mediating role of non - financial performance and to create a comparison between TQM applying companies \& non - TQM applying companies and ISO adopters and non - ISO adopters to find the customization of TQM application in Vietnamese enterprises. Hence, the purposes of research are twofold:

(1) Investigating the mediator role of non-financial performance in the relationship between TQM practices and financial performance,

(2) Comparing the situation of TQM companies \& non - TQM companies as well as ISO adopters \& non - ISO adopters in the role of non-financial performance mediator.

The estimation results propose that non - financial performance plays an essential role as a mediator in the relationship between TQM practices and financial performance in the Vietnamese context. There is no difference between not only TQM companies \& non - TQM companies but also ISO adopters \& non - ISO adopters in the mediating effect of non - financial performance. However, the research suggested that Vietnamese enterprises should have strictly commitment to putting TQM philosophy in actions at this early step of TQM implementation process to achieve high benefits in long- term development.

\section{Literature review}

\subsection{Quality and total quality management}

Total quality management is one of the popular managerial concepts in developed countries; however, it is a new concept for developing economies such as emerging economies. The root of TQM definitions comes from quality explanations. In general, quality was defined as a predictable degree of uniformity and dependability at a low cost and suited to the market (Deming, 2018). On the other hand, Cosby and Juran's definition focused on designing products and services that meet customers' needs and expectations (Madu, 1998). Kiran (2017) explained quality as "fitness for use", "fitness for purpose", "customer satisfaction", "conformance to the requirements" or has a pragmatic interpretation as non- interiority or superiority of something. In ISO 9000, quality described "the degree to which a set of inherent characteristics fulfills requirements". Therefore, according to Peter Drucker: "quality is not what the supplier puts in, it is what the customer gets out and is willing to pay for". Basing on the concept of quality, the idea of total quality management has been developed as a result of intense global competition (Ahmad et al., 2014). Definition of TQM is a controversial topic among researchers because of distinctions between TQM content, elements, and processes. Focused on content, TQM has been considered as a management philosophy or the major business strategy in the 1990s (Witcher, 1994; Leung et al., 1999) or one form of operations management practices (Jung and Wang, 2006). According to Abdullah (2010), TQM is "a philosophy and a set of guiding principles" to combine not only management techniques but also technical tools as well as improvement efforts in a stable technical system with continuous improvement targets for managing a firm. Furthermore, TQM is used as a way of continuous improvement (Goh \& Ridgway, 1994; Hackman \& Wageman, 1995), and it has been recognized as a commitment to customers. In the research of Kanji (1990), TQM is a guarantee for customer satisfaction through continuous improvement. So, implementation of TQM can reduce costs, increase profits, and secure market share, as Berry (1991) explained: the TQM process as a total corporate with the target to meet and exceed customers' expectations and to reduce costs. For the implementation of TQM, it covers the whole organization for understanding each activity of each individual at each level (Dahlgaard et al., 2008). Madu (1998) also defined TQM is "as an organization-wide quality program to continuously improve products and services delivered to customers by developing supportive organizational culture and implementing statistical and management tools". This definition shows that TQM is a holistic concept for improving the quality of products and services by involving all processes and activities in companies for ensuring quality management. For this concept, quality management is responsibilities for not only quality department or board of directors but also all employees in the organization. Achieving the totality of TQM requires joint collaborative efforts of all departments and all members of the company, as Wilkinson and Witcher (1993) defined. TQM contains three simple equations: Total - means participation of everyone; Quality - means meeting customer requirements accurately, and Management - means enabling conditions for total quality. 


\subsection{TQM factors}

Clarifying the components of TQM, Oakland $(1990,2014)$ represented five components of TQM as a pyramid, including management commitment, customer-supplier chain, quality systems, Statistical Process Control (SPC) tools, and teamwork. Meanwhile, Lakhe and Mohanty (1994) showed that TQM combined with two primary functions - total quality control and quality management - may ensure and improve product-process quality, working environment, and working culture. This research emphasized TQM as "organization-wide activity" and "continuous quest for excellence" to prevent the possibility of defects and to satisfy customers or consumers at all times by doing the right skills and attitudes in every individual within a firm. Sharing the same point, Zaire and Simintiras (1991) defined that TQM is the combination of "socio-technical process" and "economic viability" at each stage of each process with the target doing the right external and internal things at the first time and all the time. Dale et al. (2007) explained TQM as the implementation of quality management principles in the whole organization and the integration of customers and suppliers in the central business process. In general, TQM can be described as "a combination of participatory management and teamwork, produce defect-free products or customer satisfaction". It includes the human and the quality-productivity relationship; compromises the process in which requires improving performance at all levels and activities of everyone in the organization (Cetindere et al., 2015). More specifically, according to Menon (1992), TQM elements involve strategic management, employee involvement, supplier involvement, leadership, continuous improvement, cost of quality, statistical analysis, internal customers. From these elements, TQM improves quality, productivity, and worker satisfaction as well as reduced cost. As a consequence, the final results in TQM systems are meeting customer satisfaction, increasing market share, and improving job security. A numerous research concerned about the critical TQM factors, Saraph et al. (1998) identified 8 TQM factors (role of top management, role of quality department, training, product/service design, supplier quality management, process management, quality data and reporting, employee relations), Black and Porter (1996) studied with 10 TQM factors (corporate quality culture, strategic quality management, teamwork structures, external interface management, supplier partnership, operational quality training, quality improvement measurement systems, communication of improvement information, people and customer management, customer satisfaction orientation), Agus and Abdullah (2000) tested for 5 TQM factors (top management commitment, supplier relationship, training, employee focus, customer focus) and so on. In this research, TQM has been considered as the multi-dimensional constructs with six significant components represented for TQM practices in Vietnamese enterprises:

\section{Leadership}

Top management leadership concerned about the extent to set up objectives and strategies for quality management as well as to provide and allocate organizational resources. Also, leadership was recognized in the contribution of quality improvement efforts, the assessment of quality management implementation, and performance (Saraph et al., 1989). TQM theory identified that with a full commitment to a total quality setting, leaders could organize and synergize employee's activities to achieve the common goal of the organization. Additionally, senior management must understand the purpose and principles of TQM and should also consider the internal strategic management process, training and development, participation of staff, and the role in implementing the TQM approaches. Senior management must understand the purpose and principles of TQM and should also consider the internal strategic management process, training and development, participation of staff, and the role in implementing the TQM approaches. Saraph et al. (1989) concerned that the purpose of management leadership and quality policy included not only acceptance of quality responsibility by top managers, evaluation of senior management on quality but also participation of top management in the quality improvement process. Besides, setting quality goals, attach to quality with cost and schedule, comprehensive quality planning is the role of leadership management. Because of providing the vision and direction to employees, improving the ability of information sharing and enhancing communication process, enhancing synergies value addition and bringing enlightenment, leadership is not only one of essential TQM elements to influence and improve other TQM factors but also one of the most critical factor contributing to successful TQM program (Crosby, 1979). It is impossible to apply quality management and improve performance without strong top management support (Flynn et al., 1994).

\section{Process management}

Process management emphasizes preventing and proactive approaches to quality management through a set of methodological and behavioral practices (Sadikoglu \& Zehir, 2010). Design foolproof of and stable production schedules and work distribution to reduce variations and improve the quality of product in the production state, less reliance on inspection, prevent maintenance are some activities of process management (Flynn et al., 1995; Saraph et al., 1989; Kaynak, 2003).

\section{Quality information}

Quality information is essential for managers in decision - making. Based on the reviewing, analyzing quality data and information, organizations can achieve strategic objectives and responsibilities for internal and external changes. (Sadikoglu \& Zehir, 2010). Providing critical data and information is a key success for managers in a total quality setting. Therefore, focused on quality information activity during TQM practice process, firms should be accomplish with: Use of quality cost data, 
feedback of quality data to employees and managers for problem-solving, timely quality measurement, evaluation of managers and employees based on quality performance, availability of quality data (Saraph et al., 1998; Antony et al., 2002; Kaynak, 2003; Demirbag et al., 2006).

\section{Employee training}

Saraph et al. (1989) concerned that training activities included the provision of statistical training, trade training, and qualityrelated training for all employees. Moreover, supervision skills, communication, teamwork, customer relations involved in training topics (Flynn et al., 1994).

\section{Customer focus}

Customer focus is a core concept for TQM practices as well as an essential part of firm production because producing and delivering products/services also referred to achieve customer's needs and expectations to ensure for long - term success and survival (Deming, 2018; Sadikoglu \& Zehir, 2010).

\section{Supplier management}

The research of Deming (2018) indicated the advantages of depending on fewer suppliers, and a long-term relationship built with a single supplier by trust and loyalty. So, in a TQM setting, fewer dependable suppliers, reliance on supplier process control, healthy interdependence of suppliers, and customer are set for main activities in supplier management (Saraph et al., 1989). Furthermore, selecting supplier basing on quality rather than price should be applied to improve quality practices (Hackman \& Wageman, 1995).

\subsection{Firm performance factors}

For firm performance concept, according to Richard et al. (2009), firm performance generally involved three parts of firm outcomes: financial performance representing by profits, return on assets, return on investment and so on; product market performance representing by sales, market share and so on; shareholder return representing by total shareholder return, economic value-added and so on. In shorten way, Cetindere et al. (2015) followed the definition that performance could be defined as the evaluation of all the efforts in pursuit of the realization of management goals. Firm performance is also known as "output of the firm's operations or achievements of firm's goals" (Maqsood, 2019). Related to the relationship with TQM practices, firm performance concept also contains a wide range of constructs like financial and market performances, quality performances, operational performance, inventory management performance, or any operator results in a period. One of the famous quality awards in the world, The Malcolm Baldrige Quality Award in the US, proposed a framework for calculating performance based on product and process results, customer-focused results, workforce - focus results, leadership and governance results, financial and market results. In other words, in the research of Dermibag et al. (2006), firm performance has been calculated by financial indicators represented by profit, market share, earnings, and growth rate, which called "past performance". Another - part of firm performance is non - financial performance, which represented for "overcome potential shortcomings of traditional organizational performance".

\section{Financial performance}

Measuring financial performance is essential in evaluating the success of management methods like TQM because financial performance and accounting measures are justified either the impact of most technologies and investments or the reflection of the company's strategy and implementation to firm value (Moballeghi \& Moghaddam, 2011). The impact of TQM on financial performance can be investigated in two categorizes subjective measures (by people's perceptions) and objective measures (by reported profit figures) (Kober et al., 2012). Related to financial performance variables, because of concentrated on retaining customers, improving product design efficiency as well as reducing costs which lead to increase revenues; sales, market share, profits are financial performance indicators (York \& Miree, 2004). Many researchers (Powell, 1995; Nguyen et al., 2016; Kaynak, 2003) supported for measuring financial performance by profit, sales, growth, market results. At the same time, others advocated for some specific indicators, for instance: return on investment, return on assets, cash flow (Agus \& Abdullah, 2000; Demirbag et al., 2006). These accounting indicators usually are retrieved from the companies' annual reports that commons for listed companies in the stock market. This research conducts for Vietnamese enterprises which are not listed companies, the writer calculates financial performance by subjective data with two sets of indicators: Profitability (revenue growth, sales growth and profit growth) and market results (market share, market share growth and new market/new customers growth), these variables come from the research of Nguyen et al. (2016); Kaynak (2003); York \& Miree (2004).

\section{Non-financial performance}

Non - financial performance is another critical component of firm performance in the relationship with TQM practices. Non - financial performance has related to quality performance, and the measurements for quality performance can be described 
in product or service quality, productivity, cost of scrap and rework, delivery lead -time. As Shaukat at al. (2002), quality performance was considered as "a composite measure of all aspects of an organization's supplier, product, process, and service quality performance". Therefore, the successful measurement of the TQM program by quality performance is a measurement of customer satisfaction and employee satisfaction. In this research, non - financial performance contains three elements: product \& customer results, process results, workforce results basing on the study of Nguyen et al. (2016), U1 Hassan et al. (2013), Demirbag et al. (2006), Sadikoglu \& Zehir (2010) and framework of The Malcolm Baldrige Quality Award 2017.

\subsection{Relationship between TQM, firm performance, financial performance, and non - financial performance}

In this relationship between TQM and firm performance, some mediators were studied such as: lean manufacturing practices, innovation capability, 5S \& TPM, organizational learning, organizational citizenship, national culture, SPC (Hana Arrfou et al., 2016; Fullerton \& Wempe, 2009; Mahmud et al., 2019; Seth \& Tripathi, 2005; Almad et al., 2015; and so on). Furthermore, a wide range of researches focused on the relationship between TQM implementation and firm performance in different contexts. In the level of nations, many countries in both developed and developing nations have been chosen such as: Malaysia, Australia, Spain, US, Turkey, Singapore, India, Greece, Pakistan, Qatar, Taiwan, Mexico, Indonesia, Thailand, Korea, Germany, Japan, Saudi Arabica, Ireland, Jordan, Libya, and Vietnam, and so on. A significant relationship between TQM and firm performance is shown in most of the previous articles (Ahmad et al., 2013, 2015). Regarding the relationship between TQM practices and financial performance, non - financial performance, there is some empirical research with mixed results (Demirbag et al., 2006; Duh et al., 2012). Some researchers used stock price performance to measure firm performance, while others developed indicators by themselves (Kaynak, 2003; Samson \& Terziovski, 1999; Prajogo \& Sohal, 2006). In the research of Demirbag et al. (2006) conducted in Turkish SMEs, it revealed that TQM practices had a strong relationship with non-financial performance and only a weak influence on financial performance. On the other hand, Hendricks and Singhal (1997) and Easton \& Jarrell (1998), Douglas \& Judge (2001) proved that effective TQM practices improves financial performance. However, when control variables as firm size, risk, time of application were taken into account, the relationship between TQM practices and firm performance changed. In the research of Kober et al. (2012) in Australia found that no evidence about improvement of financial performance in TQM companies after controlling for size and risk. In some cases, financial performance may not receive a direct effect from TQM practices but receive an indirect impact from TQM practices through non-financial performance (Kaynak, 2003; Kober et al., 2012, Demirbag et al., 2006). Implementation of total quality management (TQM) has been ensuring the sustainable development of firms in many countries and moving toward TQM is one of the continuous improvement trends for firms after getting some quality standards. In Vietnam, companies applying TQM have been increasing gradually since quality management systems were introduced in 1995 . However, Vietnamese enterprises have been still struggled for implementing TQM effectively due to lack of human resources, instructions, or operational support and tools. For the link between TQM and organizational performance, Nguyen at al. (2016) evaluated the practices of TQM and organizational performance in 400 construction companies in Hanoi with six factors, including market and profitability, customer satisfaction, employee satisfaction, process efficiency, process effectiveness and order time. The research demonstrated the strong relationship between both by using multiple regression analysis. However, the study only investigated in the construction area in Hanoi and organizational performance. In a different aspect, Nguyen at al. (2018) discovered the contribution of 4 quality management activities - top management support for quality management, design for quality, quality data \& reporting, and continuous improvement to sustainable performance, which were economic performance, environmental performance, and social performance. The results of the research showed a positive effect on social performance while it submitted a mixed impact on financial performance and environmental performance.

\subsection{Relationship between ISO 9000 and TQM}

Han et al. (2007) concluded that ISO 9000 certification efforts and TQM practices have a significant and positive relationship, and ISO 9000 may be the first step for TQM implementation. Furthermore, Abdullah (1999) suggested that ISO 9000 provided a structured approach for the development and implementation of quality management systems. Still, it only considered as a minimal standard for excellent quality management system. Therefore, companies should consider implementing ISO 9000 as the first milestone in the path to TQM and quality excellence.

\section{Hypotheses development \& research model}

TQM practices has been showed diversified relationship with financial performance, for example, negative effect (Wali \& Boujelbene, 2011), weak influence (Demirbag et al., 2006), strong correlation (Kaynak, 2003). According to Kaplan \& Norton (1996), quality improvement, customer satisfaction, reduction in cycle time, employee empowerment are objectives of TQM, and financial performance is one of the important TQM performances. TQM programs accompany with improving customer satisfaction, process efficiency, organizational learning \& growth, as a consequence, improved financial performance (Simani, 2017). Therefore, this research expected the following hypothesis:

$\Rightarrow$ H1: TQM practices have a positive direct effect on financial performance. 
According to Demirbag et al. (2006), non - financial performance is an essential indicator in implementing TQM principles, which have an indirect effect on financial performance. Many researchers support for the positive relationship with non financial performance (Maqsood et al., 2019; Demirbag et al., 2006; Kaynak, 2003; Samson \& Terziovski, 1999).

Thus, the expectation hypothesis in this research is:

$\Rightarrow$ H2: TQM practices have a positive direct effect on non-financial performance.

Non-financial performance, which is improved quality, innovativeness, and increased market share, may reduce costs and thus have a positive effect on financial performance (York \& Miree, 2004). On the contrary, increased quality of products or services may attract customers and increase customer loyalty, which in return may improve market share and financial performance. Therefore, the hypothesis is expected that:

\section{$\Rightarrow$ H3: Non-financial performance has a positive direct effect on financial performance.}

Research of Ittner \& Larcker (1998), Kaplan and Norton (2001) indicated that non-financial performance mediated the effects on financial performance from strategic initiatives. However, prior research on TQM practices used to combine non-financial performance and financial performance as firm performance, not as distinct phenomena (Duh et al., 2012). The results of Duh et al. (2012) supported the hypothesis that non-financial performance fully mediated the relationship between TQM practices and financial performance. Generally, in this research our expectation is:

$\Rightarrow$ H4: Non - financial performance has a mediating effect on the relationship between TQM practices and financial performance.

Based on the literature review and hypothesis development, the research model is proposed as below:

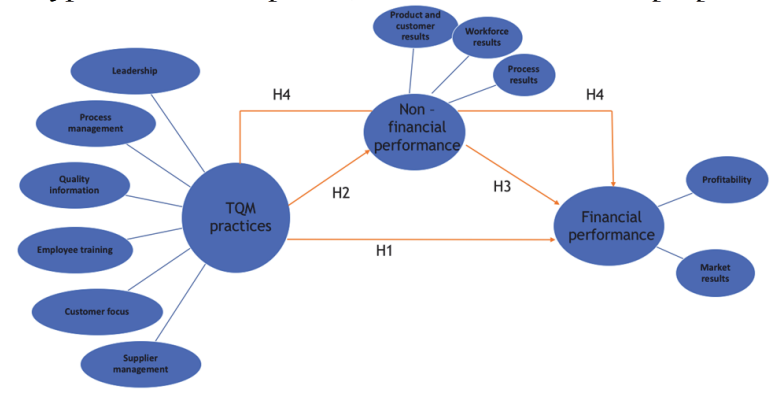

\section{Research methodology}

Fig. 1. Research model

This research designs the questionnaire to do a survey and collect data for studying the correlation between TQM practices and non - financial performance, financial performance by using SPSS 20 and AMOS 22. Most of the questions are adapted from works of Saraph et al. (1989), Nguyen et al. (2016), Kaynak (2003), Sadikoglu and Zehir (2010), Lakhal et al. (2006). The questionnaire sent to 452 Vietnamese enterprises in Ha Noi, Hai Duong, Vinh Phuc, Hai Phong, Ho Chi Minh, Ba Ria Vung Tau province to collect data from 2 types of Vietnamese companies using TQM and not using TQM. A total of 232 respondents came back; of 232 responses, 21 responses are removed because of incomplete answers. As a consequence, the sample size of this research is 211 , with the rate of response is $51.32 \%$. The table 1 presents the demographics of the sample in the study.

Table 1

Sample demographics

\begin{tabular}{|c|c|c|c|c|}
\hline & Profile & non - TQM & TQM & Total \\
\hline & Population & 103 & 108 & 211 \\
\hline \multirow{3}{*}{ Sectors } & Manufacturing & $78(75.73 \%)$ & $85(78.7 \%)$ & $163(77.25 \%)$ \\
\hline & Service & $22(21.36 \%)$ & $18(16.67 \%)$ & $40(18.96 \%)$ \\
\hline & No answer & $3(2.91 \%)$ & $5(4.63 \%)$ & $8(3.79 \%)$ \\
\hline \multirow{4}{*}{ Number of employees } & $\operatorname{Big}(>200)$ & $38(36.89 \%)$ & $44(40.74 \%)$ & $82(36.02 \%)$ \\
\hline & Medium (50 - 200) & $27(26.21 \%)$ & $33(30.56 \%)$ & $60(28.44 \%)$ \\
\hline & Small $(<50)$ & $30(29.13 \%)$ & $20(18.52 \%)$ & $50(23.7 \%)$ \\
\hline & No answer & $8(7.77 \%)$ & $11(10.18 \%)$ & $19(9 \%)$ \\
\hline \multirow{3}{*}{ Job title of respondents } & Director, CEO, managers & $53(51.46 \%)$ & $69(63.89 \%)$ & $122(57.82 \%)$ \\
\hline & Employee & $27(26.21 \%)$ & $23(21.3 \%)$ & $50(23.7 \%)$ \\
\hline & Others & $23(22.33 \%)$ & $16(14.81 \%)$ & $39(18.48 \%)$ \\
\hline
\end{tabular}


As to be seen in Table 1, respondents are mainly at top managers - directors, CEOs, managers (57.82\%) from manufacturing enterprises $(77.25 \%)$.

\section{Analysis and findings}

\subsection{Scale reliability and validity and model fitness analysis}

Testing for reliability and construct validity are essential requirements for SEM analysis. Three elements - unidimensionality, validity, and reliability should be confirmed for all constructs and models in the research before modeling in a structural model. Unidimensional assessment is the priority to assessing validity and reliability. Construct reliability of TQM, financial performance, and non - financial performance was confirmed if Cronbach's $\alpha$ value above 0.7 (Hair et al., 2006). In table 2, the minimum value of Cronbach's $\alpha$ in this research is 0.829 ; thus, it shows the considerable internal reliability of TQM constructs, financial performance constructs, and non-financial constructs. Other indicators showing the reliability of constructs are KMO (Kaiser - Meyer - Olkin) value - if greater than 0.5 and total variance of explained - if more than $50 \%$. All of the research constructs meet the requirement for KMO value and total variance of explained. Convergent validity measures for the items in a factor actually are related, it is verified by Average Varian Extracted (AVE) value which should be higher than 0.5 to achieve convergent validity (Hair et al., 2006). To be seen in Table 2, the convergent validity of the research is confirmed.

\section{Table 2}

Unidimensionality, Convergent Validity and Reliability

\begin{tabular}{|c|c|c|c|c|}
\hline Construct & Cronbach's alpha & KMO & $\begin{array}{l}\text { Composite relia- } \\
\text { bility }\end{array}$ & $\begin{array}{c}\text { Average variance extracted } \\
\text { (AVE) } \%\end{array}$ \\
\hline Leadership & 0.927 & 0.912 & 0.928 & $56.5 \%$ \\
\hline Process management & 0.88 & 0.818 & 0.885 & $65.9 \%$ \\
\hline Quality information & 0.906 & 0.791 & 0.909 & $71.6 \%$ \\
\hline Employee training & 0.882 & 0.733 & 0.884 & $71.8 \%$ \\
\hline Customer focus & 0.829 & 0.72 & 0.83 & $62.0 \%$ \\
\hline Supplier management & 0.923 & 0.5 & 0.925 & $86.1 \%$ \\
\hline Product \& customer results & 0.878 & 0.855 & 0.881 & $55.2 \%$ \\
\hline Process results & 0.871 & 0.71 & 0.877 & $70.5 \%$ \\
\hline Workforce results & 0.865 & 0.801 & 0.867 & $62.0 \%$ \\
\hline Profitability & 0.938 & 0.768 & 0.939 & $83.7 \%$ \\
\hline Market Results & 0.916 & 0.728 & 0.921 & $79.7 \%$ \\
\hline
\end{tabular}

All factor loadings are significant with the ranging from 0.508 to 0.997 to indicate that the model achieves convergent validity. The correlation between variables displayed in the table 3 , it indicates that all the variables significant correlated.

Table 3

Descriptive statistics, bivariate correlations for variables in research model

\begin{tabular}{|c|c|c|c|c|c|c|c|c|c|c|c|c|c|}
\hline & \multicolumn{6}{|c|}{ Correlations $^{\mathrm{b}}$} & \multirow[b]{2}{*}{7} & \multirow[b]{2}{*}{8} & \multirow[b]{2}{*}{9} & \multirow[b]{2}{*}{10} & \multirow[b]{2}{*}{11} & \multicolumn{2}{|c|}{$\begin{array}{c}\text { Descriptive } \\
\text { Statistics }\end{array}$} \\
\hline & 1 & 2 & 3 & 4 & 5 & 6 & & & & & & Mean & $\begin{array}{l}\text { Std. } \\
\text { Dev. }\end{array}$ \\
\hline 1.Leadership & 1 & - & - & - & - & - & - & - & - & - & - & 3.67 & 0.676 \\
\hline 2. Process management & $.631^{\text {** }}$ & 1 & - & - & - & - & - & - & - & - & - & 3.51 & 0.766 \\
\hline 3. Quality information & $.577^{* *}$ & $.627^{* *}$ & 1 & - & - & - & - & - & - & - & - & 3.35 & 0.796 \\
\hline 4 Employee training & $.565^{* *}$ & $.626^{* *}$ & $.559^{* *}$ & 1 & - & - & - & - & - & - & - & 3.47 & 0.791 \\
\hline 5. Customer focus & $.451^{* *}$ & $.435^{* *}$ & $.426^{* *}$ & $.559^{* *}$ & 1 & - & - & - & - & - & - & 3.58 & 0.755 \\
\hline 6. Supplier management & $.423^{* * *}$ & $.503^{* *}$ & $.479^{* *}$ & $.527^{* *}$ & $.526^{* *}$ & 1 & - & - & - & - & - & 3.41 & 0.834 \\
\hline 7. Product \& customer results & $.556^{* *}$ & $.619^{* *}$ & $.593^{* *}$ & $.640^{* *}$ & $.471^{* *}$ & $.516^{* *}$ & 1 & - & - & - & - & 3.59 & 0.655 \\
\hline 8. Process results & $.231^{* *}$ & $.366^{* *}$ & $.358^{* *}$ & $.374^{* *}$ & $.191^{* *}$ & $.346^{* *}$ & $.360^{* *}$ & 1 & - & - & - & 2.9 & 0.954 \\
\hline 9. Workforce results & $.493^{* *}$ & $.509^{* *}$ & $.524^{* *}$ & $.558^{* *}$ & $.462^{* *}$ & $.327^{* *}$ & $.528^{* *}$ & $.266^{* *}$ & 1 & - & - & 3.49 & 0.659 \\
\hline 10.Profitability & $.457^{* *}$ & $.543^{* *}$ & $.483^{* *}$ & $.558^{* *}$ & $.447^{* * *}$ & $.397^{* *}$ & $.535^{* *}$ & $.319^{* * *}$ & $.607^{* *}$ & 1 & - & 3.45 & 0.768 \\
\hline 11. Market results & $.367^{* *}$ & $.484^{* *}$ & $.400^{* *}$ & $.507^{* *}$ & $.402^{* *}$ & $.308^{* *}$ & $.410^{* *}$ & $.309^{* * *}$ & $.551^{* *}$ & $.663^{* *}$ & 1 & 3.42 & 0.812 \\
\hline
\end{tabular}

**. Correlation is significant at the 0.01 level (2-tailed).

b. Listwise $N=211$

Assessment of model fit, several fitness indexes are employed to test to how fit is the with database in Structural Equation Model analysis: Chi-square/df, Root Mean Square Error of Approximation (RMSEA), Comparative Fit Index (CFI), Tucker and Lewis Index (TLI), Incremental Fit Index (IFI). These goodness-of-fit statistics reflect the fitness of data to the hypothesized model in research. In this research model, the results receive from the data analysis process are: $C h i-s q u a r e / d f(C M I N)=$ 1.492 (<3); RMSEA =0.048 (<0.08); $C F I=0.936$ (>0.9), $T L I=0.931(>0.9)$, IFI $=0.937(>0.9)$, $p=0$; therefore, the structural model reveals a sufficiently good fit of the model to data (Hair et al., 2006).

\subsection{Hypothesis testing}


The model is tested by data received from the survey with 211 respondents in total by using SEM path analysis to test for four hypotheses:

\section{H1: TQM practices have a positive direct effect on financial performance.}

This hypothesis identifies the direct relation between TQM practices and financial performance. With standard $\beta=0.742^{*}(\mathrm{p}$ $<0.001)$, the hypothesis is accepted, which means TQM practices have a positive direct effect on financial performance in Vietnamese enterprises.

\section{H2: TQM practices have a positive direct effect on non - financial performance}

The second hypothesis illustrates the direct relation between TQM practices and non-financial performance. The results show that: standard $\beta=0.97^{*}(\mathrm{p}<0.001)$, the hypothesis is $\underline{\text { accepted}}$; thus, TQM practices have a positive direct effect on nonfinancial performance.

\section{H3: Non - financial performance has a positive direct effect on financial performance}

The third hypothesis tests the direct relation between TQM practices and non-financial performance. The results submit with standard $\beta=0.887^{*}(\mathrm{p}<0.001)$, the hypothesis is $\underline{\text { accepted }}$, so non-financial performance has a positive direct effect on financial performance.

H4: Non - financial performance has a mediating effect on the relationship between TQM practices and financial performance

For this hypothesis, when non - financial performance enters in the relationship between TQM practices and financial performance, the results of the hypothesis test present in Table 4 shows that: H1 and H3 are rejected because $\mathrm{p}$ - values were higher than 0.05. Only H2 is accepted, that means TQM practices have a positive direct effect on non - financial performance. However, the value of the standardized regression coefficients of the hypothesis was too high; it may represent for unreliable value in this model.

\section{Table 4}

Hypothesis test results

\begin{tabular}{lcccccc}
\hline No. & & Relationship & & Std.Beta & p-value & Hypothesis \\
\hline H1 & Financial performance & $\leftarrow$ & TQM & TQM & -3.481 & 0.692 \\
H2 & Non -financial performance & $\leftarrow$ & NOT SUPPORT & 0.985 & $<0.001$ \\
H3 & Financial performance & $\leftarrow$ & Non - financial performance & 4.280 & 0.630 & NOPPORT \\
\hline
\end{tabular}

According to Maassen and Bakker (2001), this model may occur a suppressor phenomenon; in this case, non - financial performance was suppressor variable in this model. TQM practices strongly related to non - financial performance; as a consequence, other relationships in the model between TQM practices \& financial performance and non - financial performance \& financial performance were overwhelmed. As suggestion from Maassen and Bakker (2001), the research changed to test hypothesis for total indirectly effect from TQM practices and financial performance through non - financial performance. This model only identifies the indirect relation between TQM practices and financial performance with hypothesis:

H1a: TQM practices have a positive direct effect on non - financial performance.

$\mathrm{H} 2 \mathrm{a}$ : Non - financial performance has a positive direct effect on financial performance.

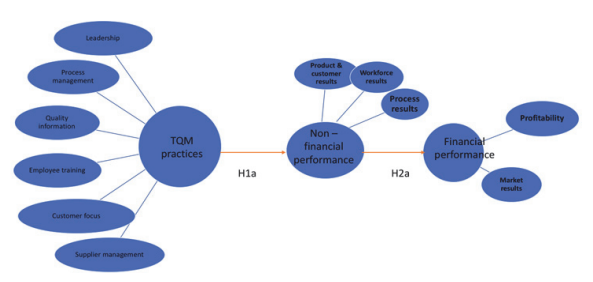

Fig. 2. Model for relationship between TQM practices and financial performance through non - financial performance

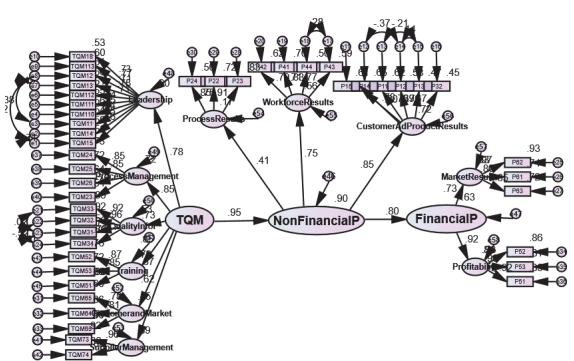

Fig. 3. Results for the mediating effect of non - financial performance 
This model has a model fit index with Chi-square $/ \mathrm{df}=1.494 ; \mathrm{RMSEA}=0.048 ; \mathrm{CFI}=0.936 ; \mathrm{TLI}=0.931 ; \mathrm{IFI}=0.937$. These indicators prove that the proposed model achieves a good fit with database. Two hypotheses are accepted in each group that means TQM practices have an indirect effect on financial performance through non - financial performance in both TQM companies and non - TQM companies. Therefore, the four hypothesis is accepted: non - financial performance has a fully mediating effect on the relationship between TQM practices and financial performance.

\section{Table 5}

Hypothesis test for the mediating effect results

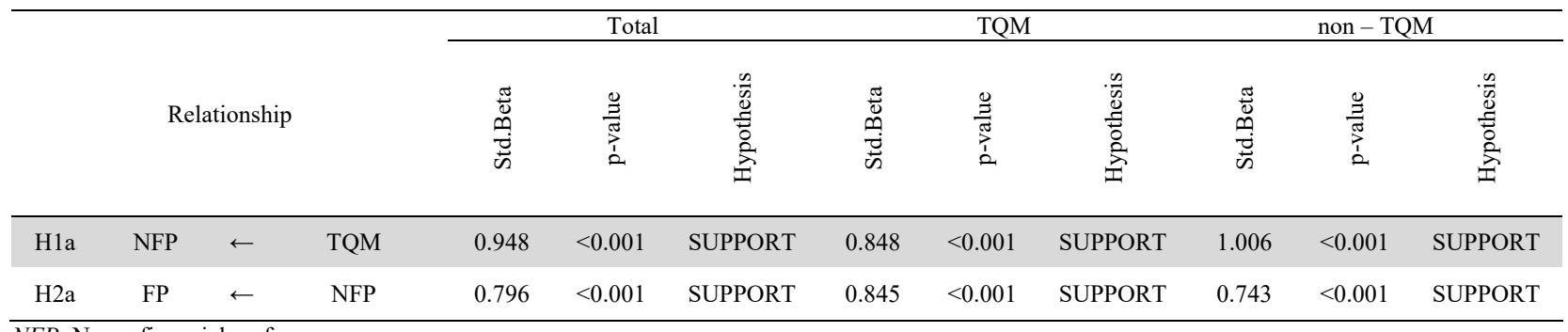

NFP: Non - financial performance

FP: Financial performance

\subsection{Multigroup analysis between TQM companies and non-TQM companies}

For comparison between TQM companies and non-TQM companies, multigroup analysis is conducted in AMOS. In this technique, the database is divided into two groups: applied TQM \& not applied TQM and ISO adopters \& non - ISO adopters. Firstly, the unconstrained model is calculated across the two groups and then the constrained model. If the change in the Chisquare value between the constrained model and the unconstrained model of multigroup analysis in SEM is statistically significant, the two groups are significant changed (Su et al., 2008).

Table 6

Multigroup analysis results

\begin{tabular}{cccccc}
\hline & Model & Chi-square & df & CFI & RMSEA \\
\hline TQM & Unconstrained model & 2823.543 & 1842 & 0.871 & 0.05 \\
situation & Constrained model & 2828.933 & 1844 & 0.87 & 0.051 \\
\hline ISO & Unconstrained model & 2798.098 & 1842 & 0.871 & 0.05 \\
situation & Constrained model & 2802.838 & 1844 & 0.871 & 0.05 \\
\hline
\end{tabular}

The results show that two model fitness indicators are good, and the Chi-square change of 5.39 at two degrees of freedom is not statistically significant $(\mathrm{p}=0.068>0.05)$. As a consequence, there is no difference in the mediating level of non-financial performance between TQM companies and non - TQM companies. Similarly, for the ISO situation, the Chi-square change of 4.74 at two degrees of freedom is not statistically significant $(p=0.09>0.05)$. Therefore, there is no different in the group of ISO adopters and the group of non - ISO adopters.

\section{Discussion}

\subsection{The mediating role of non - financial performance}

The hypothesis test investigated that TQM practices have a positive effect on non - financial performance as well as an indirect effect on financial performance through non - financial performance. Based on the results from the analysis, it is demonstrated that non - financial performance is a mediator in the relationship with TQM practices and financial performance in the Vietnamese context. In this research, non - financial performance reflected through product \& customer results, process results and workforce results and financial performance indicated by profitability (revenue growth, sales growth, profit growth) and market results (market share, market share growth, and new market/customer). This point can be explained that the competitive advantages of TQM reflected in the underlying intangible resources such as leadership management, open communication, employee empowerment (Powell, 1995), so the results of TQM practices concentrate more in non - financial performance. Besides, this research also found that the mediator of non - financial performance is a suppressor variable in the relationship between TQM practices and financial performance. In this case, non - financial performance suppressor variable involved and overwhelmed the relationship between TQM practices and financial performance. Particularly, implementation of TQM requests for a long - period time to perform improvement in financial performance, but some improvements in organizational efficiency such as satisfaction of customers, reduction of rework can be illustrated immediately. In the work of York and Miree (2004), improvement of financial performance from TQM companies appeared after five years. 
For the first time, the negative effect of TQM implementation may be discovered because of high investment. In this survey, $23,5 \%$ of TQM companies have been applied for more than five years. It cannot be denied that non - financial performance played an important role as a mediating effect on financial performance. Many researchers raise the controversial topic about whether or not TQM is valuable because many organizations adopted TQM with the expectation of quick achievement in performance, which often represent in short - term financial performance. When the short - term improvement did not appear, the failure of TQM implementation realized. So, the criticism that TQM has produced unwarranted development (Hendricks \& Singhal, 2000). The investigation of this study suggests that TQM implementation has indirect effect with financial performance through non - financial performance; therefore, TQM implementation also takes a long time and the benefits of implementation will be achieved in the long - run. Hence, the suggestion for TQM adopters in Vietnam is that the firms should have patience and keep going with the TQM implementation process. Financial performance will improve dramatically when TQM practices are implemented effectively.

\subsection{The difference between TQM enterprises \& non - TQM enterprises, ISO adopters \& non - ISO adopters}

For comparison between TQM enterprises \& non - TQM enterprises, ISO adopters \& non - ISO adopters; there is no difference in the mediating effect level of non - financial performance in these groups. This investigation demonstrates that quality management practices might not depend on the implementation of TQM or the achievement of ISO officially, it depends on the actual activities that companies have done to ensure quality management practices. Supporting for this point of view, Samson and Terziovski (1999) supposed that the TQM implementation process might produce high organizational performance while TQM philosophy was not. So, Vietnamese enterprises seem to focus on real activities to obtain quality management practices. However, Ahire et al. (1996) strongly agreed that formal TQM program should be implemented in companies not only putting TQM tools and techniques but also putting TQM philosophy officially on strategic management with a high commitment, because of the benefits in long - term vision. Furthermore, it is clear that TQM implementation process in Vietnamese enterprises is at an early step of development because more than 70\% of TQM firms in the survey applied TQM less than five years. Therefore, if Vietnamese firms want to improve quality management activities effectively, it is necessary to create engagement firmly about the target destinations for quality achievement which are directions and tangible evidences for the firm's quality management efforts.

\section{Conclusion}

The research has investigated that non - financial performance is the fully mediator in the relationship between TQM practices and financial performance and the achievement of TQM implementation will be materialized in long - run; and so, the firms should be patient to carry on this process. Although Vietnamese enterprises seem to concentrate on actual quality management activities, the research also submits that with the early development in TQM implementation process, Vietnamese enterprises should have strictly commitment to putting TQM philosophy in actions officially to achieve high benefits in long- term development.

\section{Future research}

As the recommendation in the research of Abdullah (1999) and Han et al. (2007), ISO 9000 may be a first step for total quality management. In this research, the number of ISO adopters in the TQM group accounted for around $74 \%$, and the number of future ISO registers that intend to achieve ISO certificates in the near future is nearly $20 \%$. These figures recommend for further research about the relationship between ISO situation, TQM situation, and firm performance.

\section{References}

Abdullah, M., L. (1999). Implementation of TQM, in TQM: Concepts and Practices, Asian Productivity Organization, Japan, pp 18-27.

Abdullah, A. (2010). Measuring TQM implementation: a case study of Malaysian SMEs. Measuring Business Excellence, 14(3), 3-15.

Agus, A., \& Abdullah, M. (2000). Total quality management practices in manufacturing companies in Malaysia: an exploratory analysis. Total Quality Management, 11(8), 1041-1051.

Ahire, S. L., Golhar, D. Y., \& Waller, M. A. (1996). Development and validation of TQM implementation constructs. Decision sciences, 27(1), 23-56.

Ahmad, M. F., Zakuan, N., Jusoh, A., \& Takala, J. (2013). Review of relationship between TQM and business performance. In Applied Mechanics and Materials (Vol. 315, pp. 166-170). Trans Tech Publications.

Ahmad, M. F., Zakuan, N., Jusoh, A., Yusof, S. M., Takala, J., \& Arif, M. S. M. (2014). Comparative study of TQM practices between Japanese and non-Japanese companies: Proposed conceptual framework. In Advanced Materials Research (Vol. 903, pp. 371-377). Trans Tech Publications.

Ahmad, M. F., Rasi, R. Z., Zakuan, N., \& Hisyamudin, M. N. N. (2015). Mediator effect of statistical process control between Total Quality Management (TQM) and business performance in Malaysian Automotive Industry. In IOP Conference Series: Materials Science and Engineering (Vol. 100, No. 1, p. 012067). IOP Publishing. 
Antony, J., Leung, K., Knowles, G., \& Gosh, S. (2002). Critical success factors of TQM implementation in Hong Kong industries. International Journal of Quality \& Reliability Management, 19(5), 551-566.

Berry, H.T. (1991). Managing the quality transformation. McGraw Hill, New York.

Black, S. A., \& Porter, L. J. (1996). Identification of the critical factors of TQM. Decision sciences, 27(1), 1-21.

Cetindere, A., Duran, C., \& Yetisen, M. S. (2015). The effects of total quality management on the business performance: An application in the province of Kütahya. Procedia economics and finance, 23, 1376-1382.

Crosby, P. B. (1979). Quality is free: The art of making quality certain (Vol. 94). New York: McGraw-hill.

Dahlgaard, J. J., Khanji, G. K., \& Kristensen, K. (2008). Fundamentals of total quality management. Routledge.

Dale, B. G., Van Der Wiele, T., \& Van Iwaarden, J. (2007). Managing quality. John Wiley \& Sons.

Deming, W. E. (2018). The new economics for industry, government, education. MIT press.

Demirbag, M., Tatoglu, E., Tekinkus, M., \& Zaim, S. (2006). An analysis of the relationship between TQM implementation and organizational performance: evidence from Turkish SMEs. Journal of Manufacturing Technology Management, 17(6), 829-847.

Douglas, T. J., \& Judge Jr, W. Q. (2001). Total quality management implementation and competitive advantage: the role of structural control and exploration. Academy of Management journal, 44(1), 158-169.

Duh, R. R., Hsu, A. W. H., \& Huang, P. W. (2012). Determinants and performance effect of TQM practices: An integrated model approach. Total Quality Management \& Business Excellence, 23(5-6), 689-701.

Easton, G. S., \& Jarrell, S. L. (1998). The effects of total quality management on corporate performance: an empirical investigation. The Journal of Business, 71(2), 253-307.

Flynn, B. B., Schroeder, R. G., \& Sakakibara, S. (1994). A framework for quality management research and an associated measurement instrument. Journal of Operations management, 11(4), 339-366.

Fullerton, R. R., \& Wempe, W. F. (2009). Lean manufacturing, non-financial performance measures, and financial performance. International Journal of Operations \& Production Management, 29(3), 214-240.

Goh, P. L., \& Ridgway, K. (1994). The implementation of total quality management in small and medium-sized manufacturing companies. The TQM magazine, 6(2), 54-60.

Hackman, J. R., \& Wageman, R. (1995). Total quality management: Empirical, conceptual, and practical issues. Administrative science quarterly, 309-342.

Hair, J. F. J., Black, W. C., Babin, B. J., Anderson, R. E., \& Tatham, R. L. (2006). Multivariate data analysis. Pearson Education: New Jersey.

Han, S. B., Chen, S. K., \& Ebrahimpour, M. (2007). The impact of ISO 9000 on TQM and business performance. The Journal of Business and Economic Studies, 13(2), 1.

Hana Arrfou, M., Amlus, M. H., \& Jusoh, M. S. (2016). Assessing the mediating role of lean manufacturing practices in the relationship between TQM practices and operational performance. Journal of Scientific Research and Development, 3(7), 44-53.

Hendricks, K. B., \& Singhal, V. R. (1997). Does implementing an effective TQM program actually improve operating performance? Empirical evidence from firms that have won quality awards. Management science, 43(9), 1258-1274.

Idris, M. A., McEwan, W., \& Belavendram, N. (1996). The adoption of ISO 9000 and total quality management in Malaysia. The TQM Magazine, 8(5), 65-68.

Ittner, C. D., \& Larcker, D. F. (1998). Are nonfinancial measures leading indicators of financial performance? An analysis of customer satisfaction. Journal of accounting research, 36, 1-35.

Jung, J. Y., \& Wang, Y. J. (2006). Relationship between total quality management (TQM) and continuous improvement of international project management (CIIPM). Technovation, 26(5-6), 716-722.

Kanji, G. K. (1990). Total quality management: the second industrial revolution. Total quality management, 1(1), 3-12.

Kaplan, R. S., \& Norton, D. P. (1996). Using the balanced scorecard as a strategic management system.

Kaplan, R. S., \& Norton, D. P. (2001). Transforming the balanced scorecard from performance measurement to strategic management: Part I. Accounting horizons, 15(1), 87-104.

Kaynak, H. (2003). The relationship between total quality management practices and their effects on firm performance. Journal of operations management, 21(4), 405-435.

Kiran, D. R. (2017). Total quality management: Key concepts and case studies. Butterworth-Heinemann.

Kober, R., Subraamanniam, T., \& Watson, J. (2012). The impact of total quality management adoption on small and medium enterprises' financial performance. Accounting \& Finance, 52(2), 421-438.

Lakhal, L., Pasin, F., \& Limam, M. (2006). Quality management practices and their impact on performance. International Journal of Quality \& Reliability Management, 23(6), 625-646.

Lakhe, R. R., \& Mohanty, R. P. (1994). Total quality management: concepts, evolution and acceptability in developing economies. International Journal of Quality \& Reliability Management, 11(9), 9-33.

Leung, H. K., Chan, K. C., \& Lee, T. Y. (1999). Costs and benefits of ISO 9000 series: a practical study. International Journal of Quality \& Reliability Management, 16(7), 675-691.

Maassen, G. H., \& Bakker, A. B. (2001). Suppressor variables in path models: Definitions and interpretations. Sociological Methods \& Research, 30(2), 241-270.

Madu, C. N. (1998). Strategic total quality management. In Handbook of Total Quality Management (pp. 165-212). Springer, Boston, MA. 
Mahmud, N., Hilmi, M. F., Mustapha, Y. A. A., \& Karim, R. A. (2019). Total quality management and SME performance: The mediating effect of innovation in Malaysia. Asia-Pacific Management Accounting Journal, 14(1), 201-217.

Maqsood, M. B. (2019). TQM Practices and their Effect on Non-financial Performance: An Empirical Study of Pakistani Hospitals. Health Sciences, 8(4), 147-162.

Menon, H. G. (1992). TQM in New Product manufacturing. McGraw-Hill Companies.

Moballeghi, M., \& Moghaddam, G. G. (2011). Linking TQM and financial performance. In 3rd International Conference on Information and Financial Engineering (Vol. 12, pp. 417-422).

Nguyen, A. D., Pham, C. H., \& Pham, L. (2016). Total quality management and financial performance of construction companies in Ha Noi. International Journal of Financial Research, 7(3), 41-53.

Nguyen, M., Phan, A., \& Matsui, Y. (2018). Contribution of quality management practices to sustainability performance of Vietnamese firms. Sustainability, 10(2), 375.

Oakland, J. S. (1990). Total Quality Management: a practical approach. London: Department of Trade and Industry.

Oakland, J. S. (2014). Total quality management and operational excellence: text with cases. Routledge.

Powell, T. C. (1995). Total quality management as competitive advantage: a review and empirical study. Strategic management journal, 16(1), 15-37.

Prajogo, D. I., \& Sohal, A. S. (2006). The relationship between organization strategy, total quality management (TQM), and organization performance - the mediating role of TQM. European journal of operational research, 168(1), 35-50.

Richard, P. J., Devinney, T. M., Yip, G. S., \& Johnson, G. (2009). Measuring organizational performance: Towards methodological best practice. Journal of management, 35(3), 718-804.

Sadikoglu, E., \& Zehir, C. (2010). Investigating the effects of innovation and employee performance on the relationship between total quality management practices and firm performance: An empirical study of Turkish firms. International journal of production economics, 127(1), 13-26.

Samson, D., \& Terziovski, M. (1999). The relationship between total quality management practices and operational performance. Journal of operations management, 17(4), 393-409.

Saraph, J. V., Benson, P. G., \& Schroeder, R. G. (1989). An instrument for measuring the critical factors of quality management. Decision sciences, 20(4), 810-829.

Seth, D., \& Tripathi, D. (2005). Relationship between TQM and TPM implementation factors and business performance of manufacturing industry in Indian context. International Journal of Quality \& Reliability Management, 22(3), $256-277$.

Simani, W. L. (2017). TQM perspectives under the competitive strategies and the organization performance in Kenyan manufacturing sector. Academy of Strategic Management Journal.

Su, Q., Li, Z., Zhang, S. X., Liu, Y. Y., \& Dang, J. X. (2008). The impacts of quality management practices on business performance. International Journal of Quality \& Reliability Management.

U1 Hassan, M., Hassan, S., Shaukat, S., \& Nawaz, M. S. (2013). Relationship between TQM elements and organizational performance: An empirical study of manufacturing sector of Pakistan. Pakistan Journal of Commerce and Social Sciences (PJCSS), 7(1), 1-18.

Wali, S., \& Boujelbene, Y. (2011). Cultural influences on TQM implementation and financial performance in Tunisian firms.

Wilkinson, A., \& Witcher, B. (1993). Holistic total quality management must take account of political processes. Total Quality Management, 4(1), 47-56.

Witcher, B. (1994). The adoption of total quality management in Scotland. The TQM Magazine, 6(2), 48-53.

York, K. M., \& Miree, C. E. (2004). Causation or covariation: an empirical re-examination of the link between TQM and financial performance. Journal of operations management, 22(3), 291-311.

Yusof, S. R. M., \& Aspinwall, E. (2000). TQM implementation issues: review and case study. International Journal of Operations \& Production Management, 20(6), 634-655.

Zaire, M., \& Simintiras, A. C. (1991). The sales link in the customer-supplier chain. Productivity, 32(3), 427-434.

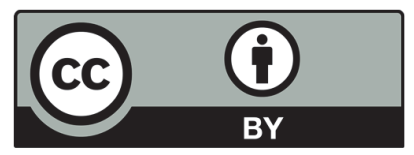

(C) 2020 by the authors; licensee Growing Science, Canada. This is an open access article distributed under the terms and conditions of the Creative Commons Attribution (CC-BY) license (http://creativecommons.org/licenses/by/4.0/). 